\title{
Will imaging change the diagnosis and management of giant cell arteritis?
}

\author{
ANDRA CHIRIAC ${ }^{1}$, CAMELIA BADEA $^{2,3}$, CRISTIAN BĂICUȘ $^{2,3}$ \\ ${ }^{1}$ Colentina Clinical Hospital, Department of Neurology, Bucharest, Romania \\ ${ }^{2}$ Carol Davila University of Medicine and Pharmacy Bucharest, Bucharest, Romania \\ ${ }^{3}$ Colentina Clinical Hospital, Department of Internal Medicine, Bucharest, Romania
}

\begin{abstract}
Giant cell arteritis is a common systemic vasculitis affecting the elderly, with maximum prevalence in the $7^{\text {th }}$ decade of age, targeting aortic derived medium and large vessels of the neck and head. Diagnosis is established on a biopsy specimen of the temporal artery wall, through pathological confirmation of panarteritis, typically characterized by mononuclear cell infiltrate, with the 1990 ACR criteria often used in clinical practice.

We present the case of a patient with a new onset headache and systemic inflammation, who did not fulfil the classical diagnostic criteria, nor did the temporal artery biopsy (TAB) provide a positive result. However, the ultrasonographical features, clinical evolution and response to corticosteroid therapy confirmed the diagnosis. This patient had bilateral presence of the halo sign on color duplex ultrasonography (CDUS), cited as a highly specific feature, when compared to the ACR criteria as a standard reference. We employed its positive likelihood-ratio (LR+) of 43 as previously estimated, while considering a low pre-test probability for a positive diagnosis $(15 \%)$, to calculate a post-test probability of $88 \%$, leading to our decision to treat him as having giant cell arteritis. Remission of the headache and rebound phenomena when tapered off steroid therapy substantially contributed to the positive diagnosis, underlining the importance of future studies needing to use clinical evolution as a reference standard.
\end{abstract}

Key words: ultrasonography, giant cell arteritis, halo sign, compression sign.

\section{INTRODUCTION}

Giant cell arteritis (GCA) is a type of systemic vasculitis occurring exclusively in the elderly population, mainly affecting the large vessels derived from the aortic arch, with the superficial temporal artery known as a predilect location. Historically, its clinical stigmata are a new onset temporal headache, jaw claudication or ocular manifestations such as amaurosis fugax or diplopia in a patient with raised biological inflammatory markers. Establishing the diagnosis employs the 1990 ACR criteria, while a positive temporal artery biopsy is commonly considered the gold-standard test. Over the last two decades, CDUS of the temporal arteries has been used as an ancillary diagnostic method, recent studies proposing it as an alternative test to the classical ones, with excellent reproducibility and interobserver agreement of the two findings: hypoechoic periluminal ring of the temporal arteries the halo sign, and visibility of the artery after transducer-imposed compression.

\section{CASE REPORT}

An 83 year old patient was addressed to our clinic for a history of persistent unilateral right headache, prominently more severe in the periauricular area, with associated ipsilateral scalp hyperesthesia. His symptoms were ongoing for the past two months, and had been unresponsive to non-steroidal antiinflammatory medication, opioid antalgics and gabapentin. Regarding his medical history, he had developed right malignant otitis externa two months prior to the first admission in our clinic, and had been subsequently treated in an ENT department with remission of the ear canal exudate. He then underwent repeated neurological consultations precluding a primary headache disorder, while a cerebral CT-scan ruled out an underlying central nervous system cause or mastoiditis. At this point, he had persistent higher values of the ESR $(41 \mathrm{~mm} / \mathrm{h})$, so he was redirected to the ENT specialist, with suspected recurrence of the ear infection, overruled by the absence of local inflammation signs. He was then prescribed an opioid antalgic and low-dose oral corticosteroid treatment (equivalent of prednisone $5 \mathrm{mg}$ daily), with very limited therapeutic response. One week later the patient presented to our clinic for the first time and upon clinical examination he was afebrile, with no recent weight loss or other constitutional signs, blood pressure was normal, he had palpable peripheral pulse in all limbs, and no cardiac murmurs or pulmonary rales were detected on auscultation. 
On neurological examination, he had hyperesthesia and allodynia of the right scalp, in the dermatome of the ophthalmic nerve, and continuous ipsilateral headache with localised increased severity in the periauricular area. Case history was negative for episodic vision loss, diplopia or ocular pain, with no evidence of clinical abnormalities of temporal arteries. He had no pain associated vegetative manifestations, such as hyperlacrimation or nasal discharge, so a trigeminal autonomic cephalalgia seemed improbable, nor did he have photo/phonophobia or nausea, to suggest migraine. He had bilateral severe hypoacusis and no other signs of cranial nerve involvement. Routine blood work revealed mildly elevated biological markers of inflammation (ESR was $48 \mathrm{~mm} / \mathrm{h}$, and CRP was $10 \mathrm{mg} / \mathrm{dL}$ ) and a normal white blood cell count. GCA emerged as a clinical suspicion, therefore a CDUS of the extracranial carotid branches was then performed, showing evidence of compression resistant hypoechoic periluminal halo of the temporal arteries, measuring $0.7 \mathrm{~mm}$ bilaterally. This warranted a TAB. With the pathology result pending, we considered a low to medium probability for a positive diagnosis of GCA, given the recent history of ear infection, yet decided to initiate corticosteroid treatment with $0.75 \mathrm{mg} / \mathrm{kg} /$ daily prednisone. A week later, the patient returned for re-evaluation, while biopsy results came back negative for inflammatory infiltrate within the vessel wall or subsequent vasculitis-associated lesions. He reported substantial pain relief, albeit with recurrence exclusively in the evening or during the night, presumably once the effect of prednisone wore off. Follow-up CDUS revealed a significantly smaller hypoechoic perivascular ring of the right temporal artery, now measuring $0.3 \mathrm{~mm}$. In this setting, by correlating the presence of bilateral halo of the temporal arteries and its size reduction under glucocorticoid treatment, with aforementioned clinical findings and additional symptom relief, we established the diagnosis of GCA.

Follow up at one month after treatment initiation revealed remission of the headache, therefore we started tapering the corticosteroid medication. In the meantime, he had developed high blood pressure, and he also presented symptoms suggestive of steroid induced myopathy, manifesting as proximal muscle weakness leading to increasing difficulty in movement. One month later, he was still headache-free, but he developed steroid-induced diabetes.

Given the side effects experienced, steroid tapering was continued at a faster rate. He returned to our clinic two months later, now on the equivalent of $10 \mathrm{mg}$ of oral prednisone daily, with features suggestive of rebound: he had intermittent left hemicranial headache and scalp hyperesthesia, and there was ultrasonographic evidence of the right temporal artery halo enlargement, now measuring $1.2 \mathrm{~mm}$ (Fig. 1). There was evidence of systemic inflammation: ESR was $75 \mathrm{~mm} / \mathrm{h}, \mathrm{CRP}$ was $20 \mathrm{mg} / \mathrm{dL}$, with associated mild normochromic normocytic anaemia, hyperferritinemia and reactive thrombocytosis, and no signs of an underlying infection or malignancy on usual screening methods. Consequently, the diagnosis was now confirmed, so the corticosteroid dose was raised to the equivalent of $60 \mathrm{mg}$ of prednisone daily. His symptoms subsequently wore off, and he was later started on methotrexate, as a steroid sparing agent.

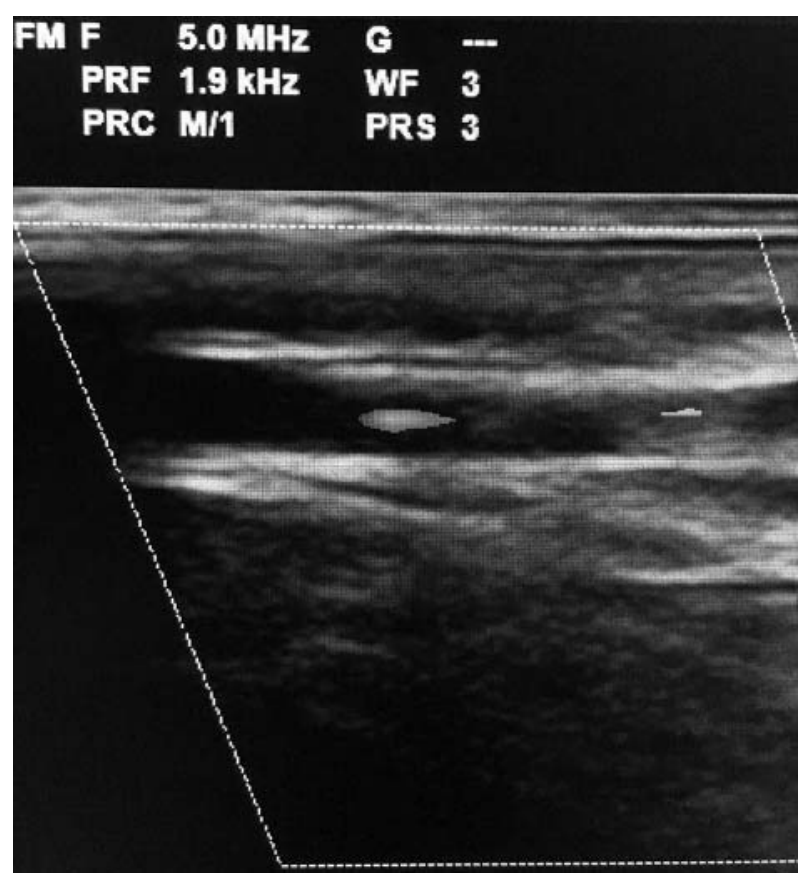

Figure 1. Right temporal artery halo enlargement measuring $1.2 \mathrm{~mm}$ (at the moment of the rebound).

\section{DISCUSSIONS}

At baseline, according to the ACR criteria and biopsy findings, this patient did not have giant cell arteritis, but two of the five ACR diagnostic criteria were met, namely the patient's age and new onset headache, with the ESR marginally close to the $50 \mathrm{~mm} / \mathrm{h}$ limit [1]. Notably, bilateral presence of the halo sign is cited as yielding a specificity of $100 \%$ for GCA, when compared to the ACR criteria as reference, showing its supremacy as a diagnostic test over clinical and biological markers classically associated with giant cell arteritis [2]. 
Among these, jaw claudication ( $\mathrm{LR}+=4.2$ ), physical examination abnormalities of the temporal arteries (LR+ varying from 4.3 to 4.6), diplopia $(\mathrm{LR}+=3.4)$ and an ESR over $100 \mathrm{~mm} / \mathrm{h}(\mathrm{LR}+=1.9)$ are the ones likeliest to predict a positive diagnosis, yet all result in only slight to moderate increases in the probability of disease, varying from 15 to $30 \%$. [3]. The clinical setting did not include any of the features relevant for the biopsy proven diagnosis: the presence of temporal headache holds only an estimated LR+ of 1.5, while any type of headache stands even lower at 1.2 [3]. Since there was no histological confirmation of vasculitis, the diagnosis of giant cell arteritis relied on the highly specific imaging features, meaning the bilateral halo of the temporal arteries $[2,3,4]$ with the added finding of the compression sign - visibility of the artery after transducer-imposed compression, suggesting vessel wall inflammation [5]. After the initial clinical assessment, we considered a pre-test probability of $15 \%$ for a positive diagnostic of GCA, which resulted in a post-test calculated probability of $88 \%$, based on the LR+ of 43 yielded by the bilateral halo sign [3]. That, in turn impacted our decision to initiate corticosteroid therapy. So, the imaging technique turned to be the key to the diagnosis, otherwise not clearly sustained by initial clinical and biological findings. Several studies also showed a potential benefit of ultrasonographic follow-up in patients exhibiting the halo sign at baseline, with evidence of regression of the wall edema in most cases, once steroid treatment was initiated. $[6,7,8,9]$. However, there is lack of congruence between the mean time to halo disappearance, ranging from 7 days in one case report [7] to a mean of 11 weeks in a 30 patients cohort study [9], with both using the $0.3 \mathrm{~mm}$ threshold in defining the halo sign. One case report showed a negative halo sign after 2 days of treatment [10]. In our case, halo disappearance (according to the same criterion) was documented 7 days after high dose oral glucocorticoid initiation, preceding complete remission of the headache, a finding similar to the report of De Miguel et al. There is a potential role of halo assessment in order to monitor disease activity, with several study showing its decrease paralleling reduction of the ESR during disease course [9]. The rebound our patient experienced once reaching a low dose of corticosteroid, encompassed raised biological markers of inflammation, recurrence of the headache and augmentation of the right temporal artery halo practically confirmed the diagnosis. It also added to the observational inference that halo monitoring may be useful in asessing arteritic flares. Others even raised the possibility of using CDUS as a method for early detection of relapses [7]. However, establishing a gold standard for comparison remains problematic, with the ideal option of repeated biopsies rendered unethical. Previous researchers looked into the diagnostic value of the halo sing by comparing it to a positive biopsy, resulting in a lower specificity, varying from $81-87 \%[4,11$, 12], a practice which excluded all patients that had the disease, but whose biopsies turned out negative due to the segmental nature of the vasculitic lesions (the so-called biopsy-negative GCA). This case suggests the possibility of using the clinical evolution as a reference standard in future studies aiming to determine the diagnostic accuracy of CDUS.

High-dose glucocorticoids remain the cornerstone of the treatment of GCA and currently the only therapeutic option available for the most dreaded complication of the disease, which is sight loss related to anterior ischemic optic neuropathy [13, 14, 15]. However, evidence-based rules regarding initial dose and administration route, treatment duration, or the appropriate manner and parameters to guide the dose tapering, have yet to be approved, so in many cases it all depends on the clinician's judgement and previous experience. $[16,17]$. In the absence of high-quality randomized control trials to confirm this, data from several retrospective studies established regimens for initial treatment include doses varying from 20 to $60 \mathrm{mg}$ of oral prednisone, for patients without impending or recent visual symptoms [13], $[14,18]$. It Is generally accepted that once clinical remission is achieved and biological markers of inflammation remain consistently within normal ranges, steroid tapering is adequate, and this is usually accomplished within one to four weeks of treatment $[13,17]$. It would be wise to consider halo monitoring as an additional mean in guiding medication tapering, but future trials are needed to confirm its use.

Arterita cu celule gigante (ACG) este o vasculită sistemică ce afectează populația vârstnică, cu un maxim de prevalență în decada a şaptea de viață, prezentând localizare țintă la nivelul vaselor medii și mari derivate din aortă, ce asigură vascularizația arterială a extremității cefalice. Diagnosticul se stabilește pe probă bioptică din peretele arterei temporale superficiale, prin panarterită confirmată histopatologic, tipic caracterizată de infiltrat inflamator de tip mononuclear, 
de menţionat fiind că în practica clinică fiind de obicei folosite criteriile ACR din 1990. Prezentăm cazul unui pacient cu cefalee de novo și sindrom biologic inflamator care nu îndeplinea criteriile diagnostice clasice, în timp ce biopsia de arteră temporală (BAT) a fost negativă. Totuși, modificările ecografice, evoluția clinică și răspunsul la corticoterapie au confirmat diagnosticul. Acest pacient prezenta semnul haloului bilateral la examinarea ecografică tip doppler color (ECD) care are o specificitate inaltă în comparație cu criteriile ACR ca gold-standard. Noi am folosit un raport de probabilitate pozitiv (LR+) anterior estimat de 43 și am considerat o probabilitate pre-test de $15 \%$, calculând astfel o probabilitate posttest de $88 \%$, ce a dus la decizia de a trata acest pacient ca având ACG. Remisia cefaleei și fenomenele de reactivare a bolii la scăderea rapidă a corticoterapiei au contribuit substanțial la stabilirea diagnosticului, subliniind necesitatea studiilor viitoare care să folosească evoluția clinică drept standard de referință.

Correspondence to: Andra Chiriac, M.D Colentina University Hospital, Department of Neurology, 19-21 Ștefan cel Mare, sector 2, 020125 Bucharest, Romania

Email: andrachiriac24@yahoo.com

Conflict of interest disclosure: The authors declare there is no conflict of interest.

\section{REFERENCES}

1. HUNDER GG., BLOCH DA., MICHEL BA., STEVENS MB., AREND WP., CALABRESE LH., et al. The American College of Rheumatology 1990 criteria for the classification of giant cell arteritis. Arthritis Rheum. 1990; 33(8):1122.

2. ARIDA A., KYPRIANOU M., KANAKIS M., SFIKAKIS PP. The diagnostic value of ultrasonography-derived edema of the temporal artery wall in giant cell arteritis: a second meta-analysis. BMC Musculoskelet Disord. 2010; 11:44.

3. SMETANA GW., SHMERLING RH. The rational clinical examination. Does this patient have temporal arteritis? JAMA. 2002; 287(1):92-101.

4. BALL E.L., WALSH S. R., TANG TY., GOHIL R., CLARKE JM. Role of ultrasonography in the diagnosis of temporal arteritis. Br J Surg. 2010; 97(12):1765-71.

5. ASCHWANDEN M., DAIKELER T., KESTEN F., BALDI T., BENZ D., TYNDALL A., et al. Temporal artery compression sign - a novel ultrasound finding for the diagnosis of giant cell arteritis. Ultraschall Med. 2013; 34(1):47-50.

6. HISHAM M., HABIB AA., ESSA AA. Color duplex ultrasonography of temporal arteries: role in diagnosis and follow-up of suspected cases of temporal arteritis. Clin Rheumatol. 2012 Feb; 31(2):231-7.

7. LARIA A., LURATI A., SCARPELLINI M. Color duplex ultrasonography findings of temporal arteries in a case of giant cell arteritis: role in diagnosis and follow-up. Open Access Rheumatol. 2017; 15 (9):55-59.

8. SCHMIDT WA. Ultrasound in the diagnosis and management of giant cell arteritis. Rheumatology (Oxford). 2018; 57(2):ii22-ii31.

9. DE MIGUEL E., ROXO A., CASTILLO C., PEITEADO D., VILLALBA A., MARTÍN-MOLA E. The utility and sensitivity of colour Doppler ultrasound in monitoring changes in giant cell arteritis. Clin Exp Rheumatol. 2012; 30(1 Suppl 70):34-8.

10. SANTORO L., D'ONOFRIO F., BERNARDI S., GREMESE E., FERRACCIOLI G., SANTOLIQUIDO A. Temporal ultrasonography findings in temporal arteritis: early disappearance of halo sign after only 2 days of steroid treatment. Rheumatology (Oxford). 2013; 52(4):622.

11. KARASSA FB., MATSAGAS MI., SCHMIDT WA., IOANNIDIS JP. Meta-analysis: test performance of ultrasonography for giant-cell arteritis. Ann Intern Med. 2005; 142(5):359-69.

12. RINAGEL M., CHATELUS E., JOUSSE-JOULIN S., SIBILIA J., GOTTENBERG JE., CHASSET F., et al. Diagnostic performance of temporal artery ultrasound for the diagnosis of giant cell arteritis: a systematic review and meta-analysis of the literature. Autoimmun Rev. 2019; 18(1):56-61.

13. PROVEN A., GABRIEL SE., ORCES C, O'FALLON WM., HUNDER GG. Glucocorticoid therapy in giant cell arteritis: duration and adverse outcomes. Arthritis Rheum. 2003; 49(5):703.

14. FRASER JA., WEYAND CM., NEWMAN NJ., BIOUSSE V. The treatment of giant cell arteritis. Rev Neurol Dis. 2008; 5(3): $140-152$.

15. AIELLO PD., TRAUTMANN JC., MCPHEE TJ., KUNSELMAN AR., HUNDER GG. Visual prognosis in giant cell arteritis. Ophthalmology. 1993; 100(4):550.

16. BUTTGEREIT F., DEJACO C., MATTESON EL., DASGUPTA B. Polymyalgia rheumatica and giant cell arteritis a systematic review. JAMA. 2016; 315(22):2442-58Cl.

17. CAMPBELL AM., MARTIN JR., ERSTAD BL. Corticosteroid tapering regimens in rheumatic disease: a systematic review.; J Clin Rheumatol. 2018 (Volume published ahead of print).

18. CHANDRAN A., UDAYAKUMAR PD., KERMANI TA., WARRINGTON KJ., CROWSON CS., MATTESON EL. Glucocorticoid usage in giant cell arteritis over six decades (1950 to 2009). Clin Exp Rheumatol. 2015; 33(2):98-102.

Received May $4^{\text {th }} 2019$ 